\title{
Wnt Signaling Alterations in the Human Spinal Cord of Amyotrophic Lateral Sclerosis Cases: Spotlight on Fz2 and Wnt5a
}

\author{
Carlos González-Fernández $^{1} \cdot$ Pau Gonzalez ${ }^{1} \cdot$ Pol Andres-Benito ${ }^{2} \cdot$ Isidro Ferrer $^{2} \cdot$ Francisco Javier Rodríguez $^{1}$ (ID
}

Received: 28 February 2018 / Accepted: 12 March 2019

(C) Springer Science+Business Media, LLC, part of Springer Nature 2019

\begin{abstract}
Amyotrophic lateral sclerosis (ALS) is a fatal neurodegenerative disorder with no cure, and elucidation of the mechanisms mediating neuronal death in this neuropathology is crucial to develop effective treatments. It has recently been demonstrated in animal models that the Wnt family of proteins is involved in this neuropathology, although its potential involvement in case of humans is almost unknown. We analyzed the expression of Wnt signaling components in healthy and ALS human spinal cords by quantitative RT-PCR, and we found that most Wnt ligands, modulators, receptors, and co-receptors were expressed in healthy controls. Moreover, we observed clear alterations in the mRNA expression of different components of this family of proteins in human spinal cord tissue from ALS cases. Specifically, we detected a significant increase in the mRNA levels of Wnt3, Wnt4, $F z 2$, and $F z 8$, together with several non-significant increases in the mRNA expression of other genes such as Wnt2b, Wnt $5 a, F z 3$, $L r p 5$, and $s F R P 3$. Based on these observations and on previous reports of studies performed in animal models, we evaluated with immunohistochemistry the protein expression patterns of Fz2 and Fz5 receptors and their main ligand Wnt5a in control samples and ALS cases. No substantial changes were observed in Fz5 protein expression pattern in ALS samples. However, we detected an increase in the amount of Fz2+ astrocytes in the borderline between gray and white matter at the ventral horn in ALS samples. Finally, Wnt5a expression was observed in neurons and astrocytes in both control and ALS samples, although Wnt5a immunolabeling in astroglial cells was significantly increased in ALS spinal cords in the same region where changes in Fz2 were observed. Altogether, these observations strongly suggest that the Wnt family of proteins, and more specifically Fz2 and Wnt5a, might be involved in human ALS pathology.
\end{abstract}

Keywords Wnt $\cdot$ Frizzled $\cdot$ ALS $\cdot$ Human $\cdot$ Spinal cord

\section{Introduction}

Amyotrophic lateral sclerosis (ALS) is the most common motoneuron $(\mathrm{MN})$ disease in human adults, with a worldwide incidence of two or three cases per year and per 100,000

Electronic supplementary material The online version of this article (https://doi.org/10.1007/s12035-019-1547-9) contains supplementary material, which is available to authorized users.

Francisco Javier Rodríguez

fjrodriguez@sescam.jccm.es

1 Molecular Neurology Group, Hospital Nacional de Parapléjicos (HNP), Finca la Peraleda s/n, 45071 Toledo, Spain

2 Department of Pathology and Experimental Therapeutics, Service of Pathologic Anatomy, IDIBELL-Bellvitge University Hospital, CIBERNED, Hospitalet de Llobregat, University of Barcelona, Barcelona, Spain population [1,2]. The degeneration affects MNs in the brain, brainstem, and spinal cord, resulting in progressive weakness and atrophy of voluntary skeletal muscles and eventually leading to death due to respiratory failure within 3 to 5 years from diagnosis [2-5]. Approximately $90 \%$ of ALS cases have an unknown etiology and are classified as sporadic, while nearly $10 \%$ are inherited or familiar, although the two forms are clinically indistinguishable and probably share common disease mechanisms [6,7]. Unfortunately, to date, the only drug approved to treat ALS, Riluzole, has a modest effect in prolonging survival $[8,9]$. One of the major handicaps in the generation of effective treatments for this fatal neurodegenerative disease is that the causes of ALS remain largely unknown, mainly due to poor understanding of the specific mechanisms that lead to the development of the disease [10, 11]. These pathophysiological mechanisms are likely to be the result of a complex interplay between several dysregulated processes, including RNA processing abnormalities, excitotoxicity, protein aggregation, defective axonal transport, 
oxidative stress, mitochondrial dysfunction, apoptosis, neuroinflammation and activation, and proliferation of astrocytes and microglia [12-14]. Another major handicap in developing new therapies is the lack of direct translation from preclinical findings to a successful clinical outcome, mainly because of the incomplete phenotypes of the models and the absence of treatment reproducibility in humans $[6,15]$. Therefore, it is critical not only to elucidate the molecular and cellular mechanisms involved in ALS in clinically relevant experimental models but also to corroborate their potential existence and relevance in humans.

Interestingly, recent studies carried out in animal models have shown that the Wnt family of proteins, a well-known regulator of crucial processes in the developing [16-18] and adult [18-20] central nervous system (CNS) under physiological conditions, is also clearly involved in many of the cellular and molecular processes that characterize the progression and outcome of different CNS pathologies [21-28]. Notably, recent studies have described a dysregulation in the expression of several members of this family of proteins in the spinal cord of a mouse model of ALS and also in an in vitro model of the disease [29-37]. However, despite these interesting observations pointing to a relevant function of the Wnt family of proteins in the progression of ALS in experimental models, there is a complete lack of information about its potential role in human ALS. Briefly, this family of proteins is composed of 19 Wnt ligands (Wnt1, 2, 2b, 3, 3a, 4, 5a, 5b, 6, 7a, 7b, 8a, 8b, 9a, 9b, 10a, 10b, 11, and 16), 10 Frizzled (Fz) receptors (Fz110 ), the LRP-5/6 co-receptors, and other non-conventional receptors such as the receptor-like tyrosine kinase (Ryk), the receptor tyrosine kinase-like orphan receptor (ROR) $1 / 2$, and the protein tyrosine kinase 7 (PTK7) [38-42]. Classically, Wnt signaling has been divided into canonical and noncanonical pathways. The canonical controls target gene transcription through the $\beta$-catenin protein, which functions as a transcriptional co-activator upon entering the nucleus. The non-canonical pathways are $\beta$-catenin-independent and are known as planar cell polarity and $\mathrm{Wnt} / \mathrm{Ca} 2+$ pathways [43-45]. All these signaling pathways are finely regulated at different levels by a wide range of regulatory molecules which includes different extracellular antagonists such as secreted Frizzled-related proteins (sFRP) 1-5, Dickkopf (Dkk) 1-4, and the Wnt inhibitory factor 1 (Wif1) [42, 46, 47].

As a first essential step to achieve a better understanding of the potential implication of the dysregulation of the Wnt family of proteins in the pathogenesis of human ALS, we aimed here to study for the first time the potential existence of alterations in the mRNA expression of the different components of the Wnt family of proteins in the spinal cord from ALS cases. Moreover and based on the results obtained and on previous reports, we analyzed, in human spinal cord samples, whether the ALS pathology correlates with changes in the protein expression and spatial distribution of Fz5, as we have previously shown in a mouse model of ALS [37], and also of Fz2 and Wnt5a, since it has been recently described that the expression of these two molecules is found altered in a mouse model of ALS [30].

\section{Materials and Methods}

\section{Human Spinal Cord Samples}

Human postmortem tissue samples of cervical, thoracic, and lumbar spinal cord levels were obtained from the HUB-ICO-IDIBELL Biobank (see Table 1 for detailed information about the human spinal cord samples used).

Table 1 Summary of human spinal cord samples used for the present study. The table shows data from human spinal cord samples obtained from control individuals (no histopathological affectation in the spinal cord) and amyotrophic lateral sclerosis (ALS) cases, and whether they were used for RT-PCR experiments, immunofluorescence (IF) or both. F: female; M: male; h: hours

\begin{tabular}{|c|c|c|c|c|c|c|}
\hline Case & Age & Gender & Diagnosis & Postmortem delay & IF & PCR \\
\hline 1 & 64 & M & Control & $10 \mathrm{~h} 40 \mathrm{~min}$ & $\mathrm{X}$ & \\
\hline 2 & 65 & M & Control & $05 \mathrm{~h} 15 \mathrm{~min}$ & $\mathrm{X}$ & \\
\hline 3 & 56 & M & Control & $07 \mathrm{~h} 10 \mathrm{~min}$ & & $X$ \\
\hline 4 & 71 & $\mathrm{~F}$ & Control & $08 \mathrm{~h} 30 \mathrm{~min}$ & $\mathrm{X}$ & $\mathrm{X}$ \\
\hline 5 & 64 & $\mathrm{~F}$ & Control & $05 \mathrm{~h} 00 \mathrm{~min}$ & $\mathrm{X}$ & $\mathrm{X}$ \\
\hline 6 & 79 & $\mathrm{~F}$ & Control & $06 \mathrm{~h} 25 \mathrm{~min}$ & & $\mathrm{X}$ \\
\hline 7 & 63 & M & Control & $03 \mathrm{~h} 50 \mathrm{~min}$ & $X$ & \\
\hline 8 & 50 & M & Control & $17 \mathrm{~h} 15 \mathrm{~min}$ & $\mathrm{X}$ & \\
\hline 9 & 76 & M & Control & $06 \mathrm{~h} 30 \mathrm{~min}$ & & $\mathrm{X}$ \\
\hline 10 & 60 & F & Control & $11 \mathrm{~h} 30 \mathrm{~min}$ & $\mathrm{X}$ & \\
\hline 11 & 47 & M & Control & $10 \mathrm{~h} 25 \mathrm{~min}$ & $\mathrm{X}$ & \\
\hline 12 & 59 & M & Control & $08 \mathrm{~h} 30 \mathrm{~min}$ & $\mathrm{X}$ & \\
\hline 13 & 51 & $\mathrm{~F}$ & Control & $04 \mathrm{~h} 00 \mathrm{~min}$ & $\mathrm{X}$ & $X$ \\
\hline 14 & 54 & $\mathrm{~F}$ & Control & $08 \mathrm{~h} 00 \mathrm{~min}$ & $\mathrm{X}$ & \\
\hline 15 & 70 & M & ALS & $03 \mathrm{~h} 00 \mathrm{~min}$ & & $\mathrm{X}$ \\
\hline 16 & 59 & M & ALS & $03 \mathrm{~h} 15 \mathrm{~min}$ & & $\mathrm{X}$ \\
\hline 17 & 67 & M & ALS & $11 \mathrm{~h} 45 \mathrm{~min}$ & $\mathrm{X}$ & \\
\hline 18 & 63 & $\mathrm{~F}$ & ALS & $13 \mathrm{~h} 50 \mathrm{~min}$ & & $X$ \\
\hline 19 & 71 & M & ALS & $08 \mathrm{~h} 45 \mathrm{~min}$ & $\mathrm{X}$ & \\
\hline 20 & 57 & M & ALS & $04 \mathrm{~h} 00 \mathrm{~min}$ & $X$ & $X$ \\
\hline 21 & 75 & $\mathrm{~F}$ & ALS & $04 \mathrm{~h} 05 \mathrm{~min}$ & $\mathrm{X}$ & $\mathrm{X}$ \\
\hline 22 & 79 & $\mathrm{~F}$ & ALS & $02 \mathrm{~h} 10 \mathrm{~min}$ & $X$ & \\
\hline 23 & 57 & $\mathrm{~F}$ & ALS & $10 \mathrm{~h} 00 \mathrm{~min}$ & $\mathrm{X}$ & \\
\hline 24 & 50 & M & ALS & $10 \mathrm{~h} 10 \mathrm{~min}$ & $\mathrm{X}$ & \\
\hline 25 & 75 & M & ALS & $03 \mathrm{~h} 00 \mathrm{~min}$ & $\mathrm{X}$ & \\
\hline 26 & 71 & M & ALS & $03 \mathrm{~h} 15 \mathrm{~min}$ & $\mathrm{X}$ & \\
\hline 27 & 59 & $\mathrm{~F}$ & ALS & $02 \mathrm{~h} 30 \mathrm{~min}$ & $\mathrm{X}$ & \\
\hline 28 & 46 & M & ALS & $07 \mathrm{~h} 00 \mathrm{~min}$ & $\mathrm{X}$ & $X$ \\
\hline 29 & 68 & $\mathrm{~F}$ & ALS & $07 \mathrm{~h} 00 \mathrm{~min}$ & $\mathrm{X}$ & \\
\hline
\end{tabular}


All individuals or relatives had given their written informed consent. Data from donors and handling of samples were carried out after approval by the Clinical Research Ethical Committee (CEIC) in Toledo (Spain) and in accordance with Spanish law and International Guidelines (LOPD 15/1999; RD 1720/2007; Helsinki declaration, 2008). Patients with associated pathology including Alzheimer's disease (excepting neurofibrillary tangle pathology stages I-II of Braak and Braak [48, 49], Parkinson's disease, tauopathies, vascular diseases, neoplastic diseases affecting the nervous system, metabolic syndrome, hypoxia and prolonged axonal states such as those occurring in intensive care units were excluded. Cases with infectious, inflammatory, and autoimmune diseases, either systemic or limited to the nervous system, were not included. Age-matched control cases had not suffered from neurologic or psychiatric diseases and did not have abnormalities in the neuropathologic examination, excepting sporadic neurofibrillary tangle pathology I-II of Braak categorization stages. No C9ORF72, SOD1, TARDBP and FUS mutations occurred in any case.

\section{RNA Extraction and Purification}

As the severe atrophy in the anterior horns of the spinal cord, with strong neuronal loss and microglia and astroglia activation, is one of the main characteristics of ALS $[12,50]$, we focused our studies on this region. RNA extraction from frozen anterior horns of the spinal cord ( $n=6$ controls and $n=6$ ALS cases) was performed with RNeasy Lipid Tissue Mini Kit (Qiagen, Hilden, DE) following instructions provided by the supplier and performing the optional DNase digest to avoid extraction and later amplification of genomic DNA. The concentration of each sample was measured at $340 \mathrm{~nm}$ with the NanoDrop, and $2 \mu \mathrm{g}$ of total RNA per sample was reverse-transcribed as described [22].

\section{Gene Expression Assays}

To test the mRNA expression of the Wnt family members, we used customized Taq-Man Array Microfluidic Cards (4342253, Applied Biosystems) previously used and validated in a recent study performed by our group [20], the TaqMan Gene Expression Master Mix (4369016, Applied Biosystems), and $20 \mathrm{ng}$ of total reverse-transcribed RNA per well. Based on our previous data [20] and the manufacturer's technical recommendations, we chose $18 \mathrm{~S}$ gene as endogenous control. All reactions were run on an ABI PRISM7900HT Fast Sequence Detection System (Applied Biosystems), and cycle threshold $(\mathrm{Ct})>35$ was considered as undetectable.

\section{Single and Double Immunofluorescence, Confocal Microscopy, and Image Analysis}

Formalin-fixed, paraffin-embedded tissue sections of 4 $5 \mu \mathrm{m}$ thick from controls $(n=11)$ and ALS cases $(n=$ 12) were dewaxed, rehydrated, and processed for immunofluorescence assays. Briefly, the sections were subjected to heat-induced antigen retrieval treatment, consisting of a 30 -min pretreatment with a $0.05 \%$ solution of citraconic anhydride (Sigma, \#27430) at $96{ }^{\circ} \mathrm{C}$, followed by temperature re-accommodation at room temperature (RT) for at least 45 additional minutes [51]. Next, sections were extensively washed with $0.1 \mathrm{M}$ TBS (pH 7.4) plus $0.1 \%$ Triton X-100 and then blocked for $1 \mathrm{~h}$ at RT with $10 \%$ fetal bovine serum and $0.3 \%$ bovine serum albumin diluted in TBS. The subsequent experimental protocol used has previously been described [22]. The following primary antibodies were used: rabbit anti-Fz2 (1:100; Abcam, ab94913), rabbit anti-Fz5 (1:100; Abcam, ab75234), rabbit anti-Wnt5a (1:50; Abcam, ab174963), mouse anti-glial fibrillary acidic protein (GFAP) (1:500; Sigma, G3893), mouse anti-Neuro-Chrom ${ }^{\text {TM }}$ Pan Neuronal (1:50; Millipore, MAB2300), and goat anti-ionized calcium binding adaptor protein 1 (Iba1) (1:100; Abcam, ab5076). Thereafter, the corresponding Dylight488-linked anti-mouse (1:500; Vector Laboratories, DI-2488), Dylight594-linked antirabbit (1:500; Vector Laboratories, DI-1594), and Alexa488-linked anti-goat (1:1000; Life technologies, A11055) secondary antibodies were used. To reduce tissue autofluorescence, sections were treated with Sudan black as previously described [52]. Briefly, at the end of the immunohistochemical procedure, the slides were immersed for $5 \mathrm{~min}$ at RT in a filtered solution of $0.5 \%$ Sudan black (Sigma, S2380) diluted in $70 \%$ ethanol. Finally, different controls were carried out to confirm a lack of undesired non-specific immunohistochemical staining. Briefly, to ensure the specificity of the primary antibodies used to visualize Fz2, Fz5, and Wnt5a, we pre-incubated these antibodies, following the protocol previously described [53], with their corresponding blocking peptides belonging to human Fz2 (Abcam, ab234541), Fz5 (Abcam, ab234542), and Wnt5a (Abcam, ab239129). Pre-incubation of the antibodies with their corresponding blocking peptides was performed with 10-fold weight/weight excess for Fz2 and 5 and with 20-fold weight/weight excess for Wnt5a. As shown (Fig. S1), antibody pre-incubation completely abolished Fz2 and 5 immunostaining, while in the case of Wnt5a, only a faint punctuate staining was observed in a thin area of subpial white matter. Moreover, to confirm a lack of undesired cross-reactivity of the different secondary antibodies used, both sections 
processed without the primary antibodies and sections processed without the second primary antibody were used as controls. Again, no non-specific staining was observed.

Qualitative microscopic evaluation of Fz2, Fz5, and Wnt5a immunoreactivity was made using a BX61 Motorized Research Microscope (Olympus), and high magnification images were acquired with a Leica TCS SP5 confocal microscope (Leica Microsystems). Quantitative image analysis was carried out in GFAP/Wnt5a composite $\times 40$ images that were taken in the ventral horns from sections processed with Wnt5a/ GFAP double immunohistochemistry using a Leica TCS SP5 resonant scanner confocal microscope (Leica Microsystems). The same acquisition settings were used to obtain GFAP, or Wnt5a images in all sample image analysis was accomplished in a blinded manner using the Fiji software [54]. In each image, a square region of interest (ROI) of $0.2 \mathrm{~mm}^{2}$ was selected in the ventral horn region, just below the transition between the GM and the WM of the anterior funiculi, where qualitative changes in Wnt5a expression were observed. The ROI analyzed represents between 6 and 19\% of the total area of the ventral horn, depending on the spinal cord level in each case. Subsequently, the single confocal plane showing the maximum immunohistochemical signal was selected in each ROI. A threshold was then established to specifically detect and quantify the area occupied by Wnt5a or GFAP staining. The selected thresholds were maintained in all analyzed images. To quantify the overlapping area between Wnt5a and GFAP in the same previously selected ROI and confocal planes, we followed an already described protocol with slight modifications [55]. More specifically, we outlined GFAP immunostaining with the previously determined thresholds and used this selected region on the corresponding Wnt5a images to calculate the Wnt5a+/GFAP+ area in each image. A total of two to six sections of the ventral horn were analyzed in each sample, and data were averaged to obtain a single value per subject.

\section{Statistical Analysis}

\section{PCR Analysis}

After averaging Cts from technical duplicates, we calculated $\Delta \mathrm{Ct}$ value in each sample (the difference between the $\mathrm{Ct}$ of each gene and the $\mathrm{Ct}$ of the housekeeping gene (18S)), and the existence of statistically significant differences between control and ALS cases in $\Delta \mathrm{Ct}$ values was determined with twotailed unpaired Student's $t$ test with statistical significance set at $p<0.05$. Data are expressed as the $2^{-\Delta \Delta \mathrm{CT}}$ mean $\pm \mathrm{SEM}$.
Statistical analyses were performed using GraphPad Prism (version 6.01).

\section{Quantitative Immunofluorescence Analysis}

The existence of significant differences between controls and ALS cases in GFAP+, Wnt5a+, and Wnt5a/GFAP+ areas was assessed with two-tailed unpaired Student's $t$ test with statistical significance set at $p<0.05$. Data are expressed as the mean \pm SEM. Statistical analyses were again performed using GraphPad Prism (version 6.01).

\section{Results}

\section{Gene Expression Dysregulation of the Wnt Family of Proteins in Spinal Cord of ALS Cases}

Evaluation of the mRNA expression of Wnt-related genes in the anterior horn of the spinal cord of controls and ALS cases demonstrates that, under both normal and pathological conditions, most Wnt ligands (Wnt2, 2b, 3, 4, 5a, 5b, 6, 7a, 7b, 8a, $8 b, 9 b, 10 a, 10 b, 11$, and 16$)$, receptors $(F z 1-10)$, co-receptors (Lrp5-6), non-conventional receptors (Ror1-2, Ptk7, and $R y k)$, and modulators (Dkkl-4, $s F R P 1-5$, and Wifl) were expressed in the adult human spinal cord (Fig. 1). We found only undetectable mRNA expression levels of Wnt1, Wnt $3 a$, and $W n t 9 a$ ligands. Moreover, we observed that ALS was associated with a clear dysregulation of the mRNA expression of several Wnt family members. Specifically, the mRNA expression of Wnt 3 and $W n t 4$ ligands and $F z 2$ and $F z 8$ receptors was significantly increased, while the mRNA levels of $W n t 2 b$, $W n t 5 a, F z 3, L r p 5$, and $s F R P 3$ showed an interesting nonsignificant increase in ALS patients (Fig. 1).

\section{Cellular and Spatial Distribution Variations of Fz2 and Absence of Changes of Fz5 in Spinal Cord of ALS Cases}

We next assessed whether the changes in mRNA expression detailed above were reflected at the protein level or whether ALS correlates with potential alterations in the spatial and/or cellular distribution of some of these molecules. Firstly, we focused on the Fz2 receptor, as it is the Wnt-related molecule that suffered the most significative change at the mRNA level in ALS cases, and recent studies have shown that its expression is increased in the spinal cord of ALS transgenic mice, specifically in astrocytes [30]. Moreover, we also analyzed the protein expression pattern of Fz5 receptor, since we recently demonstrated that its spatial and cellular expression pattern showed evident alterations in the $\mathrm{SOD} 1{ }^{\mathrm{G} 93 \mathrm{~A}}$ transgenic mouse model of ALS, even though at the mRNA level no differences were found [37]. Figure 2 shows representative images of the 
Ligands

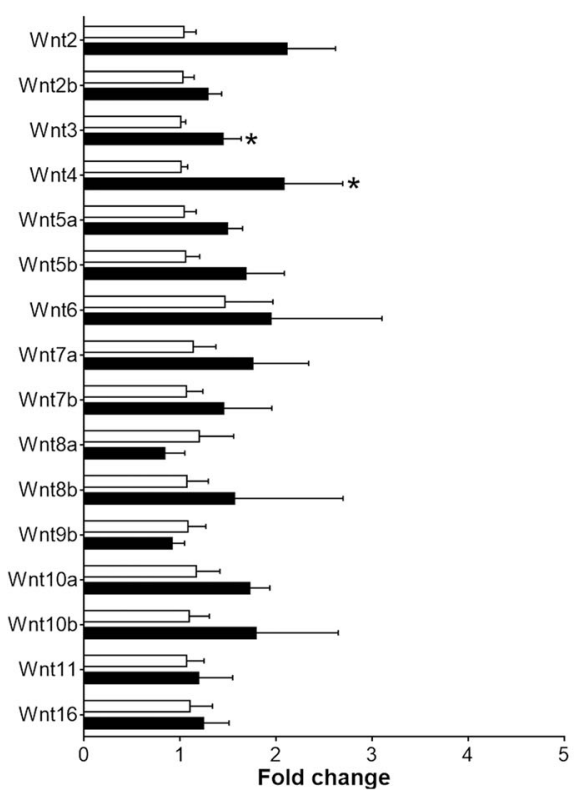

Receptors and Co-receptors

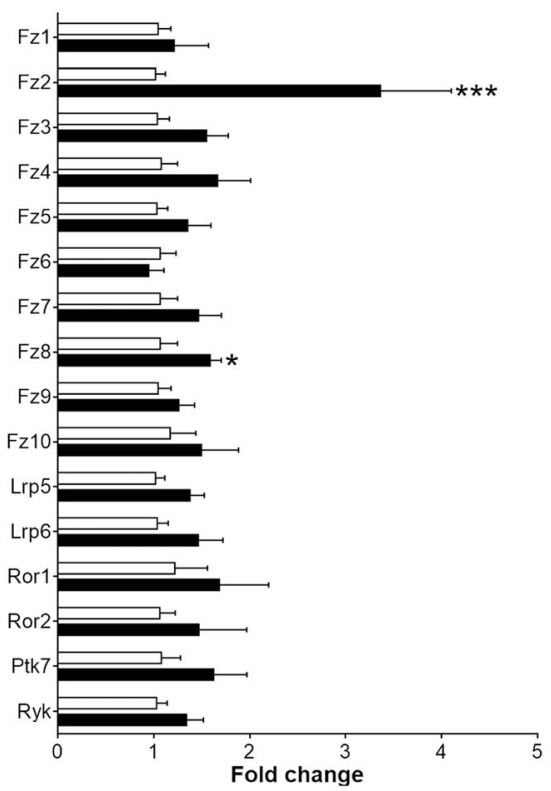

Inhibitors

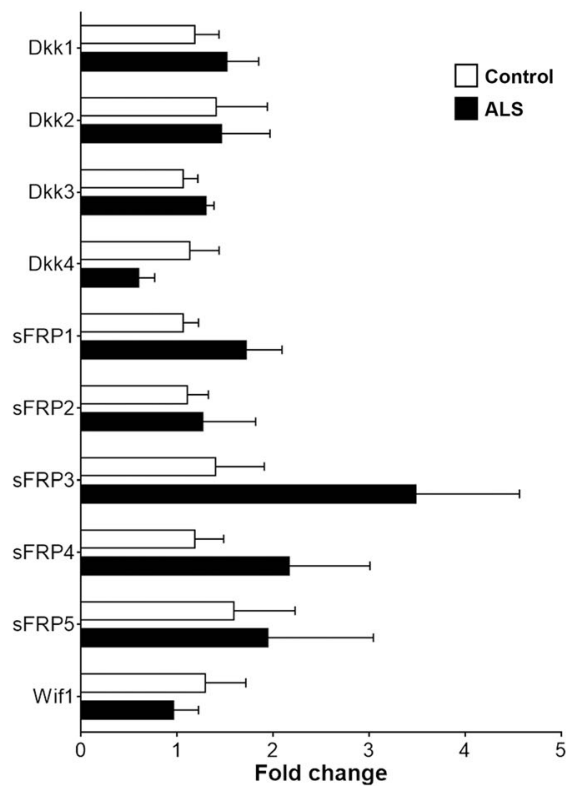

Fig. 1 Gene expression pattern alterations of different members involved in Wnt signaling pathways in the adult human spinal cord of healthy (control) and ALS cases. Almost all ligands, Fz receptors, co-receptors, unconventional receptors, and more characteristic extracellular inhibitors and modulators were detected in the ventral horn of healthy and ALS human spinal cord. Significant overexpression associated with ALS was

results obtained from the qualitative microscopic analysis of the spatial distribution of these two receptors. Again, we focused these analyses on the anterior horn of the spinal cord, which is one of the main affected areas in ALS and the specific region where we evaluated the mRNA expression of these molecules. found for Wnt3, Wnt4, $F z 2$, and $F z 8$ genes, together with several increasing tendencies that almost reached significance for $W n t 2 b$, $W n t 5 a, F z 3, L r p 5$, and $s F R P 3$ genes. Data are presented as fold change compared to control group and represent the mean \pm SEM. ${ }^{*} p<0.05$; $* * * p<0.001$

In the control healthy spinal cords, Fz2 receptor immunolabeling was mainly observed in the GM in cells displaying a neuronal-like profile, and in highly ramified cells and cellular processes mostly in the WM close to the pial surface (not shown), and to a lesser extent in the WM surrounding the GM at the ventral horn (Fig. 2a, b).
Fig. 2 Expression and distribution of Fz2 and Fz5 receptors in healthy (control) human spinal cord and ALS cases. Representative images showing the distribution of $\mathrm{Fz} 2$ and $\mathrm{Fz} 5$ receptors in the ventral horn region of the spinal cord in controls $(\mathbf{a}-\mathbf{c})$ and ALS cases (df). Both receptors showed immunoreactivity in cells with a MN profile that disappeared concomitant to the cellular death process. No more changes were detected for $\mathrm{Fz} 5$ receptor, while an increase in Fz2+ glial profiles was observed associated with ALS in the ventral horn of the spinal cord. The discontinuous line marks the boundary between the gray matter (GM) and the white matter $(\mathrm{WM})$. Scale bars = $100 \mu \mathrm{m}$

\section{Fz2}
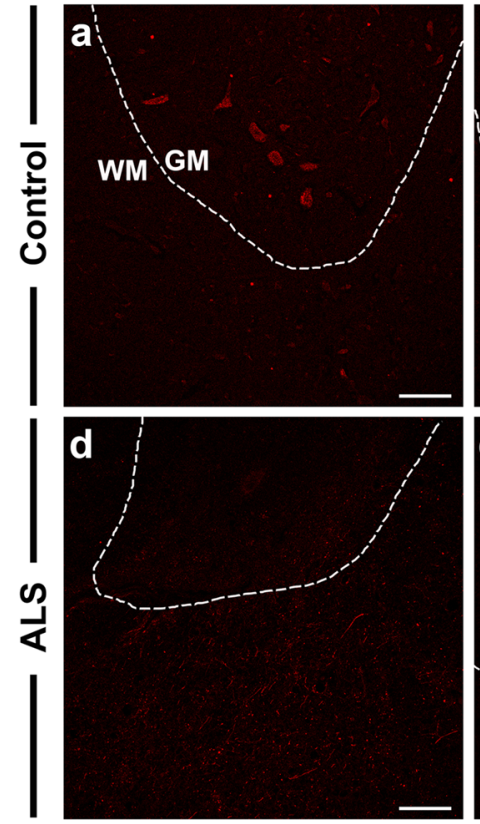

Fz2
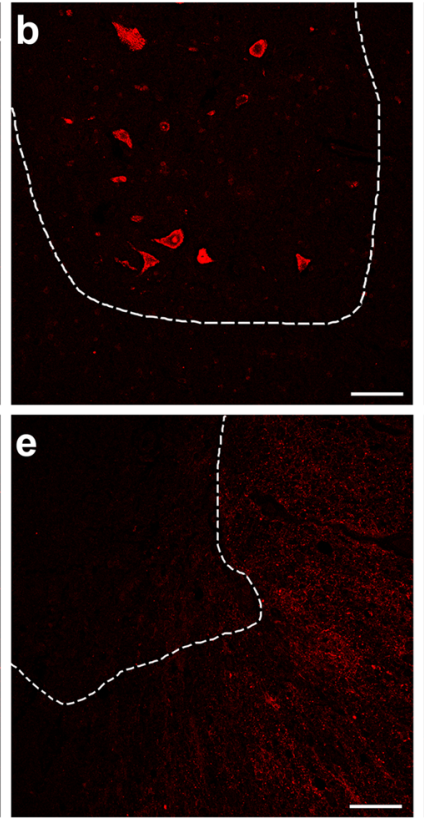

Fz5
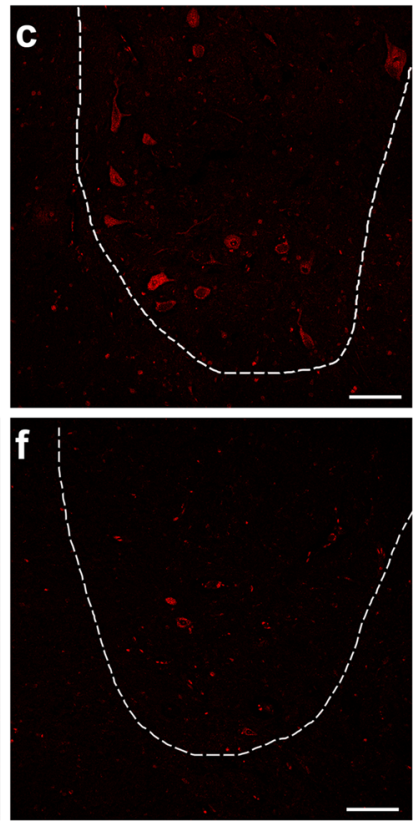


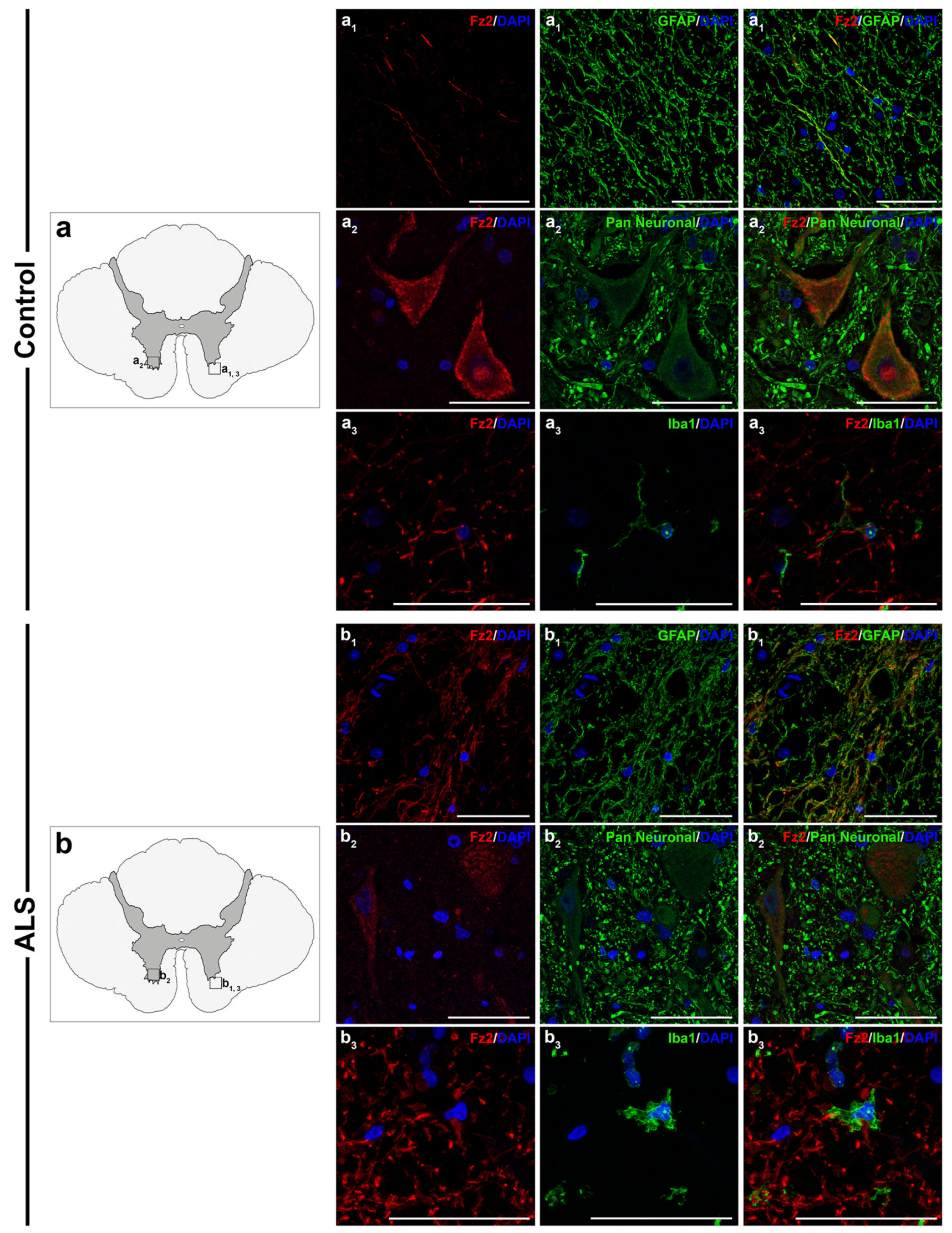


4Fig. 3 Cellular expression pattern of Fz2 receptor in healthy (control) and ALS human spinal cord. Representative images showing the expression of Fz2 by different cell types. In healthy controls, Fz2 was expressed by astrocytes $\left(a_{1}\right)$ and neurons $\left(a_{2}\right)$, but not by microglial cells $\left(a_{3}\right)$. In ALS cases, the Fz2 + cells with glial morphology that arise at ventral horn were mostly astrocytes $\left(b_{1}\right)$. Moreover, Fz2 immunolabeling was still observed in neurons $\left(b_{2}\right)$ in those individuals where neuronal cells were still present, but not in microglia $\left(b_{3}\right)$. Squares in (a) and (b) indicate areas where the different higher magnification micrographs were obtained. Scale bars $=50 \mu \mathrm{m}$

Conversely, in spinal cord samples from ALS cases, we found an evident increase in the amount of Fz2+ cellular processes and ramified cells in the WM bordering the GM in the ventral horn and, to a lesser extent, in the ventral horn GM (Fig. 2d, e). Concomitantly, an almost complete disappearance of $\mathrm{Fz} 2+$ cells displaying a neuronal-like profile was also observed, probably due to the death of ventral horn neurons that takes place during the progression of this neuropathology (Fig. $2 \mathrm{~d}, \mathrm{e})$. Interestingly, the increase in the amount of Fz2+ ramified cells in the previously detailed areas was more evident in those ALS samples that displayed a lower number of preserved MNs.

In contrast, we did not observe evident qualitative variations in the spatial expression pattern of Fz5. More specifically, Fz5 expression was clearly found in cells with a neuronal-like profile in the GM of the ventral horn of healthy spinal cords (Fig. 2c). In spinal cord samples from ALS cases, the expression pattern of Fz5 was very similar. Only a reduction of Fz5 signal was observed in this region (Fig. 2f), but once again probably due to the associated neuronal death, and not as a consequence of the loss of Fz5 receptor expression.

\section{Cellular Expression Pattern of Fz2 Receptor in Healthy and ALS Human Spinal Cord}

Based on the observations described above, we next characterized the cell types that expressed Fz2 receptor, specifically focusing on crucial cells implicated in this pathology: neurons, astrocytes, and microglia [56, 57]. In both healthy and ALS spinal cords, Fz2 receptor was expressed in neurons and astrocytes (Fig. 3, $a_{1}-a_{2}, b_{1}-$ $b_{2}$ ), but not in microglial cells (Fig. 3, $a_{3}, b_{3}$ ). However, we found that the increment in Fz2 immunolabeling observed in the ventral horn region in ALS spinal cords was due to an increase in the amount of Fz2-expressing astrocytes (Fig. 3, $b_{1}$ ). Finally, we also observed that the loss of Fz2 immunohistochemical signal in neurons in ALS samples was probably associated with the death of these cells, since in those neurons that remained alive, we still observed the expression of this receptor (Fig. 3, $\mathrm{b}_{2}$ ).

\section{Cellular Expression Pattern of Wnt5a Ligand in Healthy and ALS Human Spinal Cord}

At this point, we decided to evaluate the cellular expression pattern of Wnt5a as a potential Fz2 interacting ligand which, as previously stated, showed a clear increasing trend in its mRNA expression in spinal cord samples from ALS cases (Fig. 1). Further, the same authors that have described Fz2 alterations in ALS mice showed that Wnt5a was also upregulated in astrocytes of the transgenic mice [30]. Then, parallel to Fz2 experiments, we focused our study on the same cell types. We found that in both healthy and ALS spinal cords, Wnt5a was expressed in astrocytes (Fig. 4, $\mathrm{a}_{1}, \mathrm{~b}_{1}$ ) and neurons (Fig. 4, $a_{2}, b_{2}$ ), but not in microglial cells (Fig. 4, $a_{3}, b_{3}$ ). Moreover, we observed a qualitative increase in the amount of Wnt5a-expressing astrocytes mostly in the region of WM in close contact with GM in the anterior horn of the ALS spinal cord, where the changes in Fz2 protein expression pattern were found (Fig. 5a-f).

\section{Upregulation of Wnt5a Protein in the Spinal Cord of ALS Cases}

We subsequently quantified Wnt5a immunolabeling in astroglial cells, in the same region where the qualitative changes were found (Fig. 5a-f), to infer whether ALS correlates with changes in Wnt5a expression in this cell types and thus corroborate the previously detailed qualitative observations. Firstly, we found that Wnt5a+ area was significantly higher in ALS cases than in controls (Fig. 5g) strongly suggesting that, in accordance with the results obtained at the mRNA level, the expression of this Wnt ligand is also increased at the protein level. Secondly, we also observed that ALS led to an increase in GFAP+ area in this region (Fig. 5h), pointing to the activation of astroglial cells as previously described in ALS patients [58, 59]. Next, we found that in ALS spinal cords there was a significant increase in Wnt5a+/ GFAP+ area in this region (Fig. 5i), strongly indicating that ALS is associated with an increment in the astroglial expression of Wnt5a and that this increment is, at least in part, contributing to the increase observed in Wnt5a expression in ALS samples.

\section{Discussion}

ALS is a progressive neurodegenerative disease, described in 1869 by Jean-Martin Charcot, characterized by MN loss in the spinal cord, brainstem, and motor cortex [2, 4, 12]. ALS has been investigated for many years, and several studies have shed some light on the different mechanisms underlying this neuropathology, including impaired RNA metabolism, oxidative stress, glutamate excitotoxicity, mitochondrial 

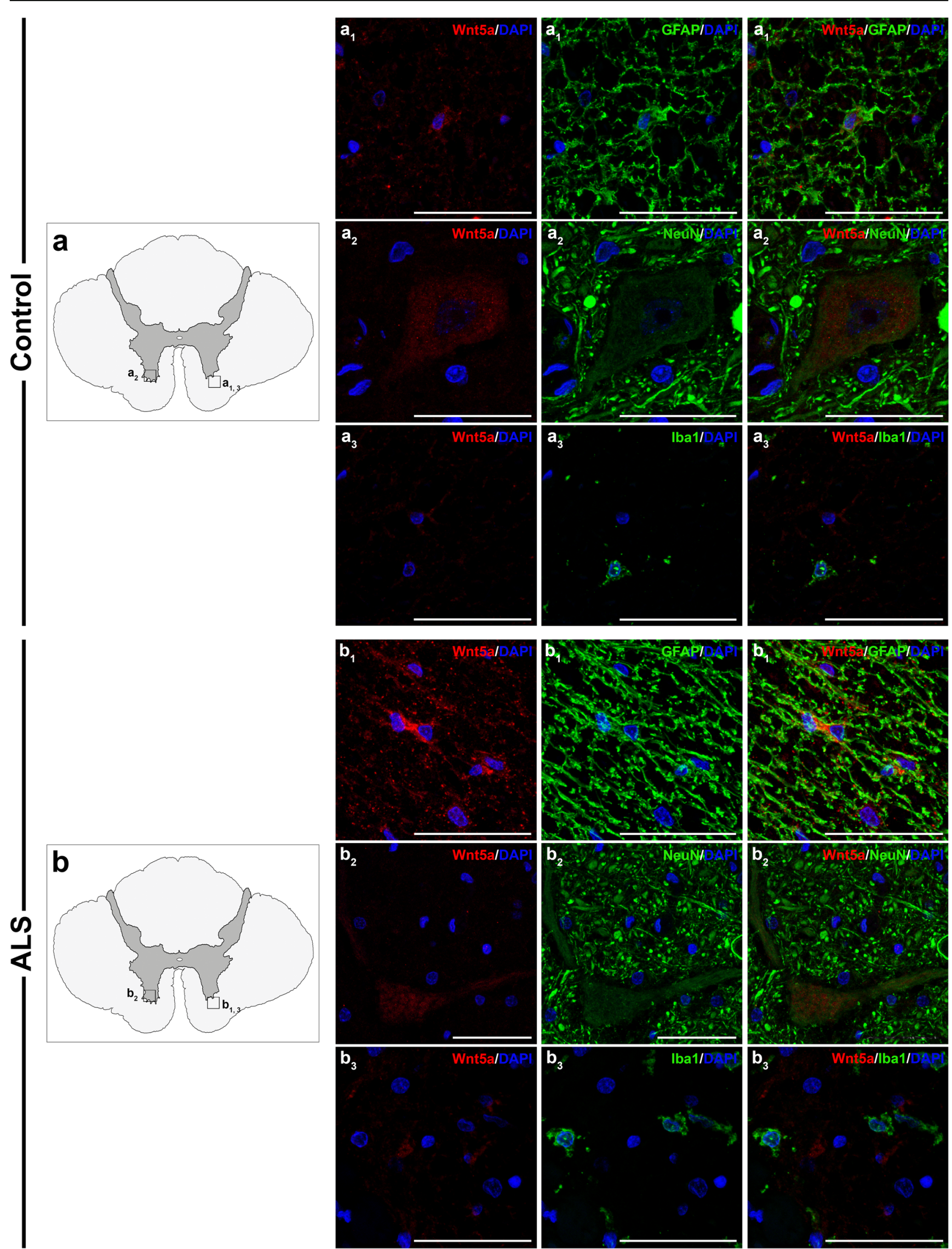
Fig. 4 Cellular expression pattern of Wnt5a ligand in healthy (control) and ALS human spinal cord. Representative images showing the expression of Wnt5a by different cell types. In both healthy and ALS samples, Wnt5a was located in astrocytes $\left(a_{1}\right.$ and $\left.b_{1}\right)$ and neurons $\left(a_{2}\right.$ and $b_{2}$ ) but not in microglial cells $\left(a_{3}\right.$ and $\left.b_{3}\right)$. Squares in (a) and (b) indicate areas where the different higher magnification micrographs were obtained. Scale bars $=50 \mu \mathrm{m}$

dysfunction, protein aggregation, autophagic dysfunction, neuroinflammation, and impaired axonal transport, among others [14, 60]. Unfortunately, no effective treatments have been identified yet to prevent or stop the neuronal death and the progression of the disease. For these reasons, it is absolutely crucial to study the different molecular mechanisms underlying this neuropathology to achieve a better comprehension of ALS progression and unravel new potential therapeutic targets. In this line, recent studies have shown that the
Wnt family of proteins, which plays key roles during CNS development [16-18] and adult homeostasis [18-20], is a critical factor involved in the progression of different neuropathologies, such as Alzheimer's disease [21, 28, 61], Huntington's disease [62, 63], Parkinson's disease [64, 65], multiple sclerosis [66, 67], glioma [68], spinal cord injury [22-25, 69, 70], and ALS [29-37].

The bulk of the knowledge relative to Wnt signaling involvement in the pathogenesis of ALS comes from SOD1 transgenic mouse models [30-37, 71, 72] and some in vitro studies [29, 33, 71, 73]. Interestingly, these reports show alterations in the mRNA expression pattern of many Wnt signaling components, including ligands, receptors, modulators, and target genes in the spinal cord of ALS mice. Furthermore, the authors describe alterations in protein levels and cellular distribution of some Wnt molecules, as for instance, Fzl and
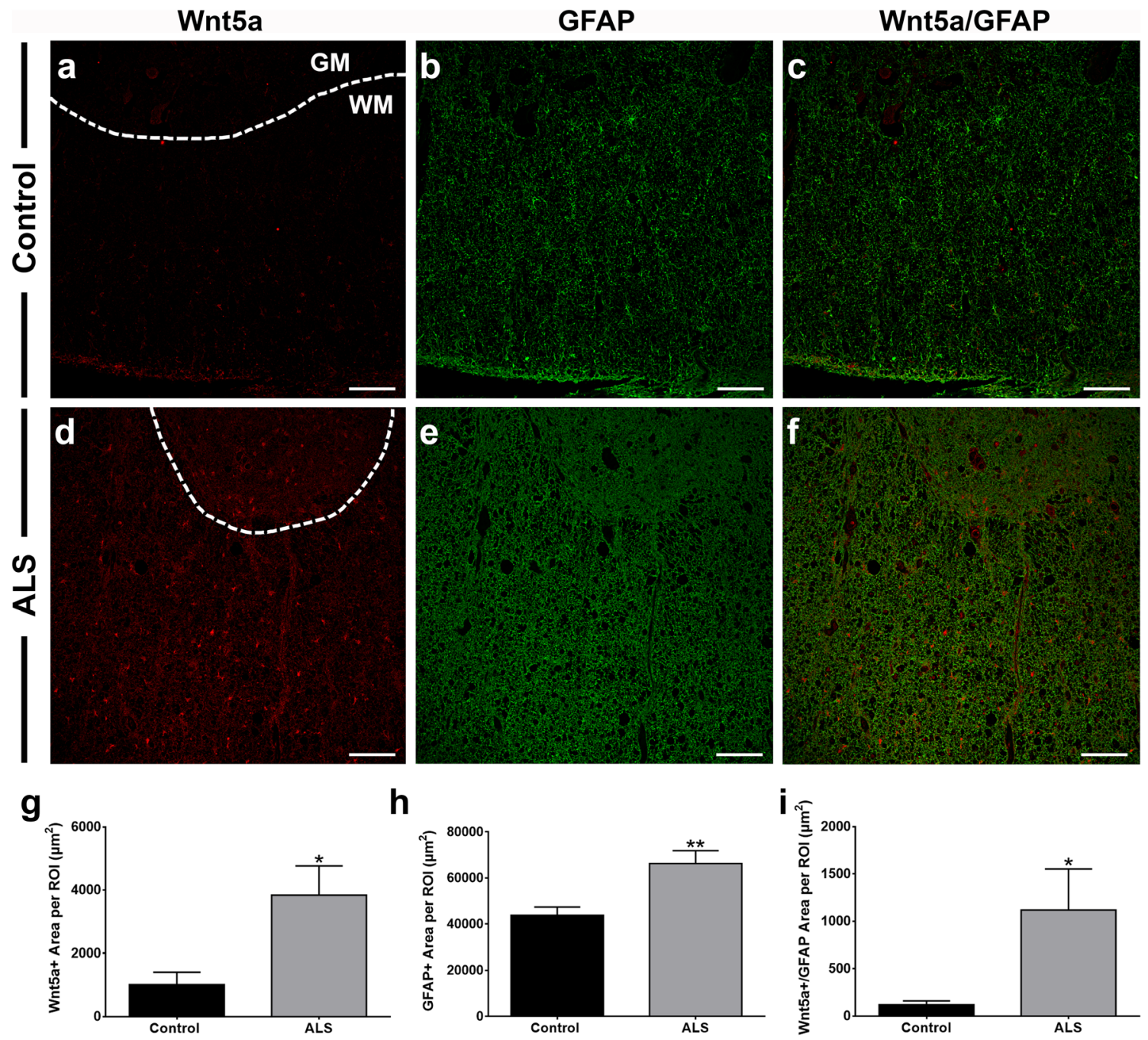

Fig. 5 Quantification of Wnt5a immunolabeling in healthy and ALS human spinal cord. Representative images $(\mathbf{a}-\mathbf{f})$ showing the region where the quantitative analysis were performed and illustrative for the alterations observed in astroglial Wnt5a expression. As shown, both Wnt5a (g) and GFAP (h) immunolabeling were significantly increased

in ALS cases compared with healthy controls in this area. Moreover, Wnt5a staining in astroglial cells was also significantly augmented in ALS spinal cords (i). Data represent the mean \pm SEM. $* p<0.05$; $* * p<0.01$. Scale bars $=100 \mu \mathrm{m}$ 
Wnt1 [33]; Wnt4 and Wif1 [31]; Ryk [32]; Wnt2, Wnt7a, and GSK3 $\beta$ [34]; Wnt3a, Cyclin D1, and $\beta$-catenin [35]; or Fz2 and Wnt5a [30], in all cases focused on the anterior horn of the mouse spinal cord and mainly related to astrocytes and MNs. Surprisingly, only one study has been published linking Wnt altered expression and ALS in humans, showing that the expression of Wnt1, 3a, 5a, 7a, and $\beta$-catenin suffered evident changes in extraocular and limb muscles of ALS subjects [36]. However, there is no information available about the existence of potential alterations in the expression of the different components of the Wnt family of proteins in the human CNS during the progression of ALS. In this complex and novel scenario, where our understanding of Wnt signaling dysregulations and their potential contribution to human ALS pathogenesis is scarce, we describe here for the first time an altered expression of Wnt family proteins in human ALS spinal cord.

Interestingly, the dysregulated expression of Wnt signaling components observed in ALS human spinal cord resembles mRNA alterations described in ALS mice spinal cord, in which it has been shown that many Wnt ligands, Fz receptors, endogenous antagonists, downstream effectors, and target genes modify their expression during the progression of the disease [30, 31, 33-35]. Although our analysis was focused on the ventral horn region and data from these studies in mice came from the analysis of the whole spinal cord section, we observed similar alterations in both cases. Remarkably, Wnt2, Wnt3, Wnt4, and specially Wnt5a ligands suffered a significant increase in their expression at final stage of disease in mice, as well as all Fz receptors and some modulators such as sFRP3 or sFRP4 [31]. In agreement with this, we have identified several genes that were significantly upregulated, such as Wnt3, Wnt4, Fz2, and Fz8, and other genes that showed an interesting non-significant increase in their mRNA expression, such as Wnt2b, Wnt5a, Fz3, Lrp5, and sFRP3. According to our results, both canonical and non-canonical Wnt signaling molecules were upregulated in ALS human spinal cord, and altogether, these observations point strongly to the potential implication of the Wnt family of proteins in the pathogenesis of the disease in humans.

Then, we aimed to examine whether these changes in mRNA expression were reflected at the protein level or whether ALS was associated with spatial and/or cellular distribution alterations of some of these molecules. As discussed above, we focused on Fz2 receptor, which seems to be the Wnt-related molecule that suffered the clearest change at the mRNA level in ALS cases, and also on Fz5, since we recently showed that its spatial and cellular expression pattern was altered in the SOD $1^{\mathrm{G} 93 \mathrm{~A}}$ transgenic mouse model of ALS [37]. In the healthy human, spinal cord Fz2 receptor was clearly expressed in neurons in the ventral horns and astrocytes mostly in the WM. In agreement with these results, we and others have shown Fz2 expression in neurons and astrocytes in the healthy adult rat [23] and mouse [30] spinal cord, as well as in non-activated cultured brain and spinal cord astrocytes [27, 74]. However, we did not detect Fz2 in microglial cells, at least at the protein level, although some reports have described low mRNA expression levels in these cells in mice [75]. Interestingly, we observed an evident increase in the amount of $\mathrm{Fz} 2+$ astrocyte in ALS cases, which was mainly identified in the transition between the GM of the horns and the WM of the anterior funiculi. Moreover, the increase in the amount of $\mathrm{Fz} 2+$ astrocytes observed was inversely correlated with the amount of preserved neurons, pointing to a connection between the degree of neurodegeneration and the amount of Fz2+ astrocytes in the affected regions. It should be noted that the Pan-neuronal marker was initially choose in order to do not miss potential changes in other neuronal populations apart from MNs, but as the alterations were observed at the ventral horn region, final studies were carried out on that area. This increase in Fz2 expression by astrocytes has also been described in a mouse model of ALS both in vivo and in primary cultures of astrocytes from transgenic mice [30]. As has been widely described [76-78], astrocytes are a key component in the maintenance of CNS environment under physiological conditions since, among other functions, they control synaptic physiology and extracellular ions and neurotransmitters levels, release neurotrophic factors, modulate blood flow, and detoxify reactive oxygen species. In ALS, aberrant astrocytic trophic support and/or secretion of neurotoxic cytokines and other molecules have been proposed as relevant factors leading to $\mathrm{MN}$ death $[52,79,80]$. These observations, together with our results showing an increase in the amount of $\mathrm{Fz} 2+$ astrocytes in ALS cases, within and around damaged regions of the spinal cord, suggest that this receptor may be involved in the pathological functioning of astrocytes in human ALS. Otherwise, we did not observe evident changes in the spatial Fz5 protein expression pattern, apart from the fading of the signal of this receptor in cells displaying a neuronal-like morphology, probably due to the death of these cells in ALS spinal cords. In contrast, in a recent publication from our group in a mouse model of ALS, we showed an increase in the immunoreactivity of Fz5 in neuronal cells concomitant with the progression of the disease [37]. This discrepancy might be explained by the existence of between-species differences, the influence of the different experimental methods used, and/or the limitations of the SOD1 transgenic model of ALS, which represents only a portion of a more heterogeneous population. 
To gain further insight into the involvement of Wnt family of proteins in ALS pathogenesis, we subsequently assessed the cellular protein expression pattern of Wnt5a as its mRNA expression seems to be upregulated in ALS spinal cords and, in different cells and circumstances, it acts as a ligand of Fz2 to activate non-canonical Wnt signaling [74, 81-83].

In agreement with a previous study performed in mice [30], we observed Wnt5a+ staining in neurons and astrocytes in the healthy human spinal cord. Although the function of physiological Wnt5a protein expression in the human spinal cord is poorly understood, it is interesting to note that Wnt5a is involved, for instance, in regulating synaptic physiology in hippocampal neurons [84, 85]. Interestingly, we show here that Wnt5a immunolabeling is significantly increased in reactive astroglial located in the affected areas of the ALS human spinal cord, where we have previously observed the detailed changes in Fz2 expression, strongly indicating that Wnt5a protein expression is augmented in this cell type. In this line, it has recently been reported that Wnt5a protein levels were significantly higher in ALS mouse spinal cord, particularly at the final stage of the disease, and that this increase in Wnt5a expression was observed mainly in astrocytes [30]. Although the potential functions of Wnt5a in the progression of ALS are currently unknown, a recent report showed that $\beta$-amyloid peptides induced the upregulation of Wnt5a in mouse primary cortical mixed neuron/glia cultures and that this increase in Wnt5a mediated the neurotoxic effects induced by these noxious stimuli, since the blockade of Wnt5a signaling using a specific antibody and the modified Wnt5a-derived hexapeptide (Box5) displayed a rescue effect on cell death, while the addition of recombinant Wnt5a or an agonistic molecule that mimics Wnt5a-induced activities (Foxy5) potentiated neurotoxicity [86]. Moreover, an important feature of ALS pathology, in common with other neurodegenerative disorders, is the reactive astrogliosis and microgliosis processes that have been described both in human [58, 59, 87] and mouse ALS spinal cord [88-90]. In mouse models, microglial cells become activated early on, before MNs disappear, and clinical disease onset [88, 89], whereas astrocytic activation seems to take place concomitantly with a decrease in neurons [91]. Interestingly, evidence from studies performed in mice has shown that Wnt5a released by astrocytes plays a critical regulatory role in the proinflammatory state of microglia [75]. In like manner, different studies have demonstrated that Wnt5a acts as a proinflammatory factor in microglial [75, 92] and astroglial cells [27], as well as suggesting its potential contribution to the inflammatory response in several disease states [75, 93-96]. These observations, together with the results obtained in the present study, point to a plausible proinflammatory role of Wnt5a in ALS pathogenesis, in which the upregulated levels of this protein would trigger a proinflammatory transformation of microglial and astroglial cells and thus further promote neurotoxicity in ALS. As we previously stated, Fz2 is able to act as Wnt5a receptor in different contexts [74, 81-83], suggesting that the potential effects of Wnt5a in astroglial and neuronal cells in human ALS cells may be, at least in part, mediated by Fz2 expression in these cell types. However, we did not find Fz2 expression in microglial cells. In this regard, it has been reported that, apart from Fz2, Wnt5a can signal through other Wnt receptors [97], and that primary mouse microglia express different Wnt receptors, making these cells responsive to recombinant purified Wnt5a [75, 98]. For instance, Fz5 is expressed in microglia/macrophage cells in the healthy and damaged spinal cord [23], while Wnt5a-Fz5 interaction is involved in the regulation of the inflammatory response in macrophages.

In summary, we demonstrate here for the first time that the gene expression pattern of Wnt signaling is altered in the anterior horn of human ALS spinal cord. Furthermore, we demonstrate that two of the Wnt family members analyzed, Fz2 and Wnt5a, are also detected at the protein level in the spinal cord of healthy controls and ALS cases. On one hand, Fz2 was expressed by neurons and astrocytes in the ventral horn of the spinal cord, and we observed an increase in the amount of Fz2 + astrocytes in ALS subjects, mainly located in the degeneration area within the ventral horn. On the other hand, Wnt5a was located in neurons and astrocytes, and we found a significant increase in the amount of this Wnt5a+ astrocytes associated with ALS pathology. Taken together, these results suggest that Wnt5a and Fz2 signaling might play a critical role in harmful processes associated with ALS such us neuronal death, astrogliosis, and microgliosis. However, it should be noted that we also found an increased expression of canonical Wnt molecules such as Wnt3 and 4 in human ALS spinal cord samples and that canonical Wnt signaling has been shown to promote neuron survival in different neuropathologies [99]. Indeed, Riluzol, which is the only approved treatment for ALS, is able to activate this Wnt signaling pathway [100]. Therefore, we cannot discard the possibility that, at least in part, the changes observed in the expression of Wnt-related molecules might conform and endogenous attempt to counteract neuronal death in ALS. In any case, our findings provide novel insights into the pathogenesis of ALS in human beings, suggesting the involvement of the Wnt family of proteins in crucial neuropathological processes in this neuropathology. Further research is needed to elucidate the particular role of Wnt-related molecules in ALS in order to identify novel therapeutic approaches to the treatment of ALS and other neurodegenerative disorders with shared neuropathological mechanisms. 
Acknowledgments We would like to thank Sandra Vázquez and Virginia Pérez for their outstanding technical help, as well as Dr. Daniel GarcíaOvejero from the Group of Neuroinflammation for sharing with us his deep knowledge and methodology on the human histology used in the study. We are extremely grateful to all individuals who agreed to donate their tissues to research.

Funding information This work was funded by the Fondo de Investigaciones Sanitarias (FIS) (Grant PI12-02895, co-funded by Fondo Europeo de Desarrollo Regional (FEDER)) from the Instituto de Salud Carlos III (ISCIII).

\section{Compliance with Ethical Standards}

Statement on the Welfare of Animals This article does not contain any studies with animals performed by any of the authors.

Conflict of Interest The authors declare they have no conflict of interests.

Statement on Sample Extraction and Processing from ALS Patients Postmortem samples from all individual participants were obtained with written informed consent prior to inclusion in the study, which has been conducted according to 1964 Declaration of Helsinki principles and its later amendments, following the ethical rule of the Hospital Universitari de Bellvitge (Spain) and according to the Directive 2004/23/EC of the European Parliament and of the Council. All samples were handled after approval by the Clinical Research Ethical Committee (CEIC) in Toledo (Spain) and in accordance with Spanish law and International Guidelines (LOPD 15/1999; RD 1720/2007; 1964 Helsinki declaration and its later amendments or comparable ethical standards).

\section{References}

1. Cleveland DW, Rothstein JD (2001) From Charcot to Lou Gehrig: deciphering selective motor neuron death in ALS. Nat Rev Neurosci 2(11):806-819. https://doi.org/10.1038/35097565

2. Morgan S, Orrell RW (2016) Pathogenesis of amyotrophic lateral sclerosis. Br Med Bull 119:87-98. https://doi.org/10.1093/bmb/ ldw026

3. Moloney EB, de Winter F, Verhaagen J (2014) ALS as a distal axonopathy: molecular mechanisms affecting neuromuscular junction stability in the presymptomatic stages of the disease. Front Neurosci 8:252. https://doi.org/10.3389/fnins.2014.00252

4. Rothstein JD (2009) Current hypotheses for the underlying biology of amyotrophic lateral sclerosis. Ann Neurol 65(Suppl 1):S3S9. https://doi.org/10.1002/ana.21543

5. Garbuzova-Davis S, Rodrigues MC, Hernandez-Ontiveros DG, Louis MK, Willing AE, Borlongan CV, Sanberg PR (2011) Amyotrophic lateral sclerosis: a neurovascular disease. Brain Res 1398:113-125. https://doi.org/10.1016/j.brainres.2011.04. 049

6. Tan RH, Ke YD, Ittner LM, Halliday GM (2017) ALS/FTLD: experimental models and reality. Acta Neuropathol 133:177196. https://doi.org/10.1007/s00401-016-1666-6

7. Gros-Louis F, Gaspar C, Rouleau GA (2006) Genetics of familial and sporadic amyotrophic lateral sclerosis. Biochim Biophys Acta 1762(11-12):956-972. https://doi.org/10.1016/j.bbadis.2006.01. 004
8. Lacomblez L, Bensimon G, Leigh PN, Guillet P, Meininger V (1996) Dose-ranging study of riluzole in amyotrophic lateral sclerosis. Amyotrophic Lateral Sclerosis/Riluzole Study Group II. Lancet 347(9013): 1425-1431

9. Miller RG, Mitchell JD, Moore DH (2012) Riluzole for amyotrophic lateral sclerosis (ALS)/motor neuron disease (MND). Cochrane Database Syst Rev 3:CD001447. https://doi.org/10. 1002/14651858.CD001447.pub3

10. Al-Chalabi A, Calvo A, Chio A, Colville S, Ellis CM, Hardiman O, Heverin M, Howard RS et al (2014) Analysis of amyotrophic lateral sclerosis as a multistep process: a population-based modelling study. Lancet Neurol 13(11):1108-1113. https://doi.org/10. 1016/S1474-4422(14)70219-4

11. Do-Ha D, Buskila Y, Ooi L (2017) Impairments in motor neurons, interneurons and astrocytes contribute to hyperexcitability in ALS: underlying mechanisms and paths to therapy. Mol Neurobiol 55: 1410-1418. https://doi.org/10.1007/s12035-017-0392-y

12. Kiernan MC, Vucic S, Cheah BC, Turner MR, Eisen A, Hardiman O, Burrell JR, Zoing MC (2011) Amyotrophic lateral sclerosis. Lancet 377(9769):942-955. https://doi.org/10.1016/S01406736(10)61156-7

13. Shaw PJ (2005) Molecular and cellular pathways of neurodegeneration in motor neurone disease. J Neurol Neurosurg Psychiatry 76(8):1046-1057. https://doi.org/10.1136/jnnp.2004.048652

14. Pasinelli P, Brown RH (2006) Molecular biology of amyotrophic lateral sclerosis: Insights from genetics. Nat Rev Neurosci 7(9): 710-723. https://doi.org/10.1038/nrn1971

15. Gladman M, Cudkowicz M, Zinman L (2012) Enhancing clinical trials in neurodegenerative disorders: lessons from amyotrophic lateral sclerosis. Curr Opin Neurol 25(6):735-742. https://doi. org/10.1097/WCO.0b013e32835a309d

16. Clevers $\mathrm{H}$ (2006) Wnt/beta-catenin signaling in development and disease. Cell 127(3):469-480. https://doi.org/10.1016/j.cell.2006. 10.018

17. Megason SG, McMahon AP (2002) A mitogen gradient of dorsal midline Wnts organizes growth in the CNS. Development 129(9): 2087-2098

18. Ciani L, Salinas PC (2005) WNTs in the vertebrate nervous system: from patterning to neuronal connectivity. Nat Rev Neurosci 6(5):351-362. https://doi.org/10.1038/nrn1665

19. Inestrosa NC, Arenas E (2010) Emerging roles of Wnts in the adult nervous system. Nat Rev Neurosci 11(2):77-86. https:// doi.org/10.1038/nrn2755

20. Gonzalez-Fernandez C, Arevalo-Martin A, Paniagua-Torija B, Ferrer I, Rodriguez FJ, Garcia-Ovejero D (2016) Wnts are expressed in the ependymal region of the adult spinal cord. Mol Neurobiol 54:6342-6355. https://doi.org/10.1007/s12035-0160132-8

21. Inestrosa NC, Toledo EM (2008) The role of Wnt signaling in neuronal dysfunction in Alzheimer's disease. Mol Neurodegener 3:9. https://doi.org/10.1186/1750-1326-3-9

22. Fernandez-Martos CM, Gonzalez-Fernandez C, Gonzalez P, Maqueda A, Arenas E, Rodriguez FJ (2011) Differential expression of Wnts after spinal cord contusion injury in adult rats. PLoS One 6(11):e27000. https://doi.org/10.1371/journal.pone.0027000

23. Gonzalez P, Fernandez-Martos CM, Gonzalez-Fernandez C, Arenas E, Rodriguez FJ (2012) Spatio-temporal expression pattern of frizzled receptors after contusive spinal cord injury in adult rats. PLoS One 7(12):e50793. https://doi.org/10.1371/journal. pone.0050793

24. Gonzalez P, Fernandez-Martos CM, Arenas E, Rodriguez FJ (2013) The Ryk receptor is expressed in glial and fibronectinexpressing cells after spinal cord injury. J Neurotrauma 30(10): 806-817. https://doi.org/10.1089/neu.2012.2613

25. Gonzalez-Fernandez C, Fernandez-Martos CM, Shields S, Arenas E, Rodriguez FJ (2013) Wnts are expressed in the spinal cord of 
adult mice and are differentially induced after injury. J Neurotrauma 31(6):565-581. https://doi.org/10.1089/neu.2013. 3067

26. Lambert C, Cisternas P, Inestrosa NC (2015) Role of Wnt signaling in central nervous system injury. Mol Neurobiol 53:22972311. https://doi.org/10.1007/s12035-015-9138-x

27. Gonzalez P, Rodriguez FJ (2017) Analysis of the expression of the Wnt family of proteins and its modulatory role on cytokine expression in non activated and activated astroglial cells. Neurosci Res 114:16-29. https://doi.org/10.1016/j.neures.2016.08.003

28. Tapia-Rojas C, Inestrosa NC (2017) Wnt signaling loss accelerates the appearance of neuropathological hallmarks of Alzheimer's disease in J20-APP transgenic and wild-type mice. J Neurochem 144:443-465. https://doi.org/10.1111/jnc. 14278

29. Pinto C, Cardenas P, Osses N, Henriquez JP (2013) Characterization of Wnt/beta-catenin and BMP/Smad signaling pathways in an in vitro model of amyotrophic lateral sclerosis. Front Cell Neurosci 7:239. https://doi.org/10.3389/fncel.2013. 00239

30. Li X, Guan Y, Chen Y, Zhang C, Shi C, Zhou F, Yu L, Juan J et al (2013) Expression of Wnt5a and its receptor Fzd2 is changed in the spinal cord of adult amyotrophic lateral sclerosis transgenic mice. Int J Clin Exp Pathol 6(7):1245-1260

31. Yu L, Guan Y, Wu X, Chen Y, Liu Z, Du H, Wang X (2013) Wnt signaling is altered by spinal cord neuronal dysfunction in amyotrophic lateral sclerosis transgenic mice. Neurochem Res 38(9): 1904-1913. https://doi.org/10.1007/s11064-013-1096-y

32. Tury A, Tolentino K, Zou Y (2014) Altered expression of atypical PKC and Ryk in the spinal cord of a mouse model of amyotrophic lateral sclerosis. Dev Neurobiol 74(8):839-850. https://doi.org/10. 1002/dneu.22137

33. Wang S, Guan Y, Chen Y, Li X, Zhang C, Yu L, Zhou F, Wang X (2013) Role of Wnt1 and Fzd1 in the spinal cord pathogenesis of amyotrophic lateral sclerosis-transgenic mice. Biotechnol Lett 35(8):1199-1207. https://doi.org/10.1007/s10529-013-1199-1

34. Chen Y, Guan Y, Zhang Z, Liu H, Wang S, Yu L, Wu X, Wang X (2012) Wnt signaling pathway is involved in the pathogenesis of amyotrophic lateral sclerosis in adult transgenic mice. Neurol Res 34(4):390-399. https://doi.org/10.1179/1743132812Y. 0000000027

35. Chen Y, Guan Y, Liu H, Wu X, Yu L, Wang S, Zhao C, Du H et al (2012) Activation of the Wnt/beta-catenin signaling pathway is associated with glial proliferation in the adult spinal cord of ALS transgenic mice. Biochem Biophys Res Commun 420(2):397403. https://doi.org/10.1016/j.bbrc.2012.03.006

36. McLoon LK, Harandi VM, Brannstrom T, Andersen PM, Liu JX (2014) Wnt and extraocular muscle sparing in amyotrophic lateral sclerosis. Invest Ophthalmol Vis Sci 55(9):5482-5496. https://doi. org/10.1167/iovs.14-14886

37. Gonzalez-Fernandez C, Mancuso R, Del Valle J, Navarro X, Rodriguez FJ (2016) Wnt signaling alteration in the spinal cord of amyotrophic lateral sclerosis transgenic mice: special focus on Frizzled-5 cellular expression pattern. PLoS One 11(5):e0155867. https://doi.org/10.1371/journal.pone.0155867

38. Hendrickx M, Leyns L (2008) Non-conventional Frizzled ligands and Wnt receptors. Develop Growth Differ 50(4):229-243. https://doi.org/10.1111/j.1440-169X.2008.01016.x

39. Fradkin LG, Dura JM, Noordermeer JN (2010) Ryks: new partners for Wnts in the developing and regenerating nervous system. Trends Neurosci 33(2):84-92. https://doi.org/10.1016/j.tins.2009. 11.005

40. Minami Y, Oishi I, Endo M, Nishita M (2010) Ror-family receptor tyrosine kinases in noncanonical Wnt signaling: their implications in developmental morphogenesis and human diseases. Dev Dyn 239(1):1-15. https://doi.org/10.1002/dvdy.21991
41. Schulte G (2010) International Union of Basic and Clinical Pharmacology. LXXX. The class Frizzled receptors. Pharmacol Rev 62(4):632-667. https://doi.org/10.1124/pr.110.002931

42. Niehrs C (2012) The complex world of WNT receptor signalling. Nat Rev Mol Cell Biol 13(12):767-779. https://doi.org/10.1038/ nrm3470

43. Cadigan KM, Liu YI (2006) Wnt signaling: complexity at the surface. J Cell Sci 119(Pt 3):395-402. https://doi.org/10.1242/ jcs.02826

44. Angers S, Moon RT (2009) Proximal events in Wnt signal transduction. Nat Rev Mol Cell Biol 10(7):468-477. https://doi.org/10. $1038 / \mathrm{nrm} 2717$

45. Widelitz R (2005) Wnt signaling through canonical and noncanonical pathways: recent progress. Growth Factors 23(2):111116. https://doi.org/10.1080/08977190500125746

46. Kawano Y, Kypta R (2003) Secreted antagonists of the Wnt signalling pathway. J Cell Sci 116(Pt 13):2627-2634. https://doi.org/ $10.1242 /$ jcs. 00623

47. Bovolenta P, Esteve P, Ruiz JM, Cisneros E, Lopez-Rios J (2008) Beyond Wnt inhibition: new functions of secreted Frizzled-related proteins in development and disease. J Cell Sci 121(Pt 6):737746. https://doi.org/10.1242/jcs.026096

48. Braak H, Braak E (1991) Neuropathological stageing of Alzheimer-related changes. Acta Neuropathol 82(4):239-259

49. Braak H, Alafuzoff I, Arzberger T, Kretzschmar H, Del Tredici K (2006) Staging of Alzheimer disease-associated neurofibrillary pathology using paraffin sections and immunocytochemistry. Acta Neuropathol 112(4):389-404. https://doi.org/10.1007/ s00401-006-0127-z

50. Mancuso R, Navarro X (2017) Sigma-1 receptor in motoneuron disease. Adv Exp Med Biol 964:235-254. https://doi.org/10.1007/ 978-3-319-50174-1 16

51. Garcia-Ovejero D, Arevalo-Martin A, Paniagua-Torija B, Florensa-Vila J, Ferrer I, Grassner L, Molina-Holgado E (2015) The ependymal region of the adult human spinal cord differs from other species and shows ependymoma-like features. Brain 138(Pt 6):1583-1597. https://doi.org/10.1093/brain/awv089

52. Johann S, Heitzer M, Kanagaratnam M, Goswami A, Rizo T, Weis $\mathrm{J}$, Troost D, Beyer C (2015) NLRP3 inflammasome is expressed by astrocytes in the SOD1 mouse model of ALS and in human sporadic ALS patients. Glia 63(12):2260-2273. https://doi.org/10. 1002/glia.22891

53. Paniagua-Torija B, Arevalo-Martin A, Molina-Holgado E, Molina-Holgado F, Garcia-Ovejero D (2015) Spinal cord injury induces a long-lasting upregulation of interleukin-1beta in astrocytes around the central canal. Neuroscience 284:283-289. https://doi.org/10.1016/j.neuroscience.2014.10.013

54. Schindelin J, Arganda-Carreras I, Frise E, Kaynig V, Longair M, Pietzsch T, Preibisch S, Rueden C et al (2012) Fiji: an open-source platform for biological-image analysis. Nat Methods 9(7):676682. https://doi.org/10.1038/nmeth.2019

55. Paniagua-Torija B, Arevalo-Martin A, Ferrer I, Molina-Holgado E, Garcia-Ovejero D (2015) CB1 cannabinoid receptor enrichment in the ependymal region of the adult human spinal cord. Sci Rep 5:17745. https://doi.org/10.1038/srep17745

56. Barbeito AG, Mesci P, Boillee S (2010) Motor neuron-immune interactions: the vicious circle of ALS. J Neural Transm 117(8): 981-1000. https://doi.org/10.1007/s00702-010-0429-0

57. Lee J, Hyeon SJ, Im H, Ryu H, Kim Y, Ryu H (2016) Astrocytes and microglia as non-cell autonomous players in the pathogenesis of ALS. Exp Neurobiol 25(5):233-240. https://doi.org/10.5607/ en.2016.25.5.233

58. Kawamata T, Akiyama H, Yamada T, McGeer PL (1992) Immunologic reactions in amyotrophic lateral sclerosis brain and spinal cord tissue. Am J Pathol 140(3):691-707 
59. Schiffer D, Cordera S, Cavalla P, Migheli A (1996) Reactive astrogliosis of the spinal cord in amyotrophic lateral sclerosis. J Neurol Sci 139(Suppl):27-33

60. Vucic S, Kiernan MC (2009) Pathophysiology of neurodegeneration in familial amyotrophic lateral sclerosis. Curr Mol Med 9(3): 255-272

61. Caricasole A, Copani A, Caraci F, Aronica E, Rozemuller AJ, Caruso A, Storto M, Gaviraghi G et al (2004) Induction of Dickkopf-1, a negative modulator of the Wnt pathway, is associated with neuronal degeneration in Alzheimer's brain. J Neurosci 24(26):6021-6027. https://doi.org/10.1523/JNEUROSCI.138104.2004

62. Wei H, Qin ZH, Senatorov VV, Wei W, Wang Y, Qian Y, Chuang DM (2001) Lithium suppresses excitotoxicity-induced striatal lesions in a rat model of Huntington's disease. Neuroscience 106(3): 603-612

63. Godin JD, Poizat G, Hickey MA, Maschat F, Humbert S (2010) Mutant huntingtin-impaired degradation of beta-catenin causes neurotoxicity in Huntington's disease. EMBO J 29(14):24332445. https://doi.org/10.1038/emboj.2010.117

64. L'Episcopo F, Tirolo C, Testa N, Caniglia S, Morale MC, Cossetti C, D'Adamo P, Zardini E et al (2011) Reactive astrocytes and Wnt/ beta-catenin signaling link nigrostriatal injury to repair in 1-methyl-4-phenyl-1,2,3,6-tetrahydropyridine model of Parkinson's disease. Neurobiol Dis 41(2):508-527. https://doi.org/10.1016/j.nbd. 2010.10.023

65. Parish CL, Castelo-Branco G, Rawal N, Tonnesen J, Sorensen AT, Salto C, Kokaia M, Lindvall O et al (2008) Wnt5a-treated midbrain neural stem cells improve dopamine cell replacement therapy in parkinsonian mice. J Clin Invest 118(1):149-160. https:/doi. org/10.1172/JCI32273

66. Yuan S, Shi Y, Tang SJ (2012) Wnt signaling in the pathogenesis of multiple sclerosis-associated chronic pain. J NeuroImmune Pharmacol 7(4):904-913. https://doi.org/10.1007/s11481-0129370-3

67. Xie C, Li Z, Zhang GX, Guan Y (2014) Wnt signaling in remyelination in multiple sclerosis: friend or foe? Mol Neurobiol 49(3):1117-1125. https://doi.org/10.1007/s12035013-8584-6

68. McCord M, Mukouyama YS, Gilbert MR, Jackson S (2017) Targeting WNT signaling for multifaceted glioblastoma therapy. Front Cell Neurosci 11:318. https://doi.org/10.3389/fncel.2017. 00318

69. Liu Y, Wang X, Lu CC, Kerman R, Steward O, Xu XM, Zou Y (2008) Repulsive Wnt signaling inhibits axon regeneration after CNS injury. J Neurosci 28(33):8376-8382. https://doi.org/10. 1523/JNEUROSCI.1939-08.2008

70. Miyashita T, Koda M, Kitajo K, Yamazaki M, Takahashi K, Kikuchi A, Yamashita T (2009) Wnt-Ryk signaling mediates axon growth inhibition and limits functional recovery after spinal cord injury. J Neurotrauma 26(7):955-964. https://doi.org/10.1089/ neu.2008.0776

71. Chen Y, Wang Q, Wang Q, Liu H, Zhou F, Zhang Y, Yuan M, Zhao C et al (2017) DDX3 binding with CK1 epsilon was closely related to motor neuron degeneration of ALS by affecting neurite outgrowth. Am J Transl Res 9(10):4627-4639

72. de Oliveira GP, Maximino JR, Maschietto M, Zanoteli E, Puga RD, Lima L, Carraro DM, Chadi G (2014) Early gene expression changes in skeletal muscle from SOD1(G93A) amyotrophic lateral sclerosis animal model. Cell Mol Neurobiol 34(3):451-462. https://doi.org/10.1007/s10571-014-0029-x

73. Bhinge A, Namboori SC, Zhang X, VanDongen AMJ, Stanton LW (2017) Genetic correction of SOD1 mutant iPSCs reveals ERK and JNK activated AP1 as a driver of neurodegeneration in amyotrophic lateral sclerosis. Stem Cell Rep 8(4):856-869. https://doi.org/10.1016/j.stemcr.2017.02.019
74. Niu LJ, Xu RX, Zhang P, Du MX, Jiang XD (2012) Suppression of Frizzled-2-mediated Wnt/Ca(2)(+) signaling significantly attenuates intracellular calcium accumulation in vitro and in a rat model of traumatic brain injury. Neuroscience 213:19-28. https://doi.org/ 10.1016/j.neuroscience.2012.03.057

75. Halleskog C, Dijksterhuis JP, Kilander MB, Becerril-Ortega J, Villaescusa JC, Lindgren E, Arenas E, Schulte G (2012) Heterotrimeric G protein-dependent WNT-5A signaling to ERK1/2 mediates distinct aspects of microglia proinflammatory transformation. J Neuroinflammation 9:111. https://doi.org/10. 1186/1742-2094-9-111

76. Yamanaka K, Komine O (2017) The multi-dimensional roles of astrocytes in ALS. Neurosci Res 126:31-38. https://doi.org/10. 1016/j.neures.2017.09.011

77. Pekny M, Pekna M (2014) Astrocyte reactivity and reactive astrogliosis: costs and benefits. Physiol Rev 94(4):1077-1098. https://doi.org/10.1152/physrev.00041.2013

78. Rossi D (2015) Astrocyte physiopathology: at the crossroads of intercellular networking, inflammation and cell death. Prog Neurobiol 130:86-120. https://doi.org/10.1016/j.pneurobio.2015. 04.003

79. Nagai M, Re DB, Nagata T, Chalazonitis A, Jessell TM, Wichterle H, Przedborski S (2007) Astrocytes expressing ALS-linked mutated SOD1 release factors selectively toxic to motor neurons. Nat Neurosci 10(5):615-622. https://doi.org/10.1038/nn1876

80. Barbeito LH, Pehar M, Cassina P, Vargas MR, Peluffo H, Viera L, Estevez AG, Beckman JS (2004) A role for astrocytes in motor neuron loss in amyotrophic lateral sclerosis. Brain Res Brain Res Rev 47(1-3):263-274. https://doi.org/10.1016/j.brainresrev.2004. 05.003

81. Sato A, Yamamoto H, Sakane H, Koyama H, Kikuchi A (2010) Wnt5a regulates distinct signalling pathways by binding to Frizzled2. EMBO J 29(1):41-54. https://doi.org/10.1038/emboj. 2009.322

82. Bazhin AV, Tambor V, Dikov B, Philippov PP, Schadendorf D, Eichmuller SB (2010) cGMP-phosphodiesterase 6, transducin and Wnt5a/Frizzled-2-signaling control cGMP and $\mathrm{Ca}(2+)$ homeostasis in melanoma cells. Cell Mol Life Sci 67(5):817-828. https:// doi.org/10.1007/s00018-009-0214-0

83. Ding S, Xu Z, Yang J, Liu L, Huang X, Wang X, Zhuge Q (2017) The involvement of the decrease of astrocytic Wnt5a in the cognitive decline in minimal hepatic encephalopathy. Mol Neurobiol 54(10):7949-7963. https://doi.org/10.1007/s12035-016-0216-5

84. Varela-Nallar L, Alfaro IE, Serrano FG, Parodi J, Inestrosa NC (2010) Wingless-type family member 5A (Wnt-5a) stimulates synaptic differentiation and function of glutamatergic synapses. Proc Natl Acad Sci U S A 107(49):21164-21169. https://doi.org/ 10.1073/pnas.1010011107

85. Farias GG, Alfaro IE, Cerpa W, Grabowski CP, Godoy JA, Bonansco C, Inestrosa NC (2009) Wnt-5a/JNK signaling promotes the clustering of PSD-95 in hippocampal neurons. J Biol Chem 284(23):15857-15866. https://doi.org/10.1074/jbc. M808986200

86. Li B, Zhong L, Yang X, Andersson T, Huang M, Tang SJ (2011) WNT5A signaling contributes to Abeta-induced neuroinflammation and neurotoxicity. PLoS One 6(8):e22920. https://doi.org/10. 1371/journal.pone.0022920

87. Turner MR, Cagnin A, Turkheimer FE, Miller CC, Shaw CE, Brooks DJ, Leigh PN, Banati RB (2004) Evidence of widespread cerebral microglial activation in amyotrophic lateral sclerosis: an [11C](R)-PK11195 positron emission tomography study. Neurobiol Dis 15(3):601-609. https://doi.org/10.1016/j.nbd. 2003.12.012

88. Alexianu ME, Kozovska M, Appel SH (2001) Immune reactivity in a mouse model of familial ALS correlates with disease progression. Neurology 57(7):1282-1289 
89. Hall ED, Oostveen JA, Gurney ME (1998) Relationship of microglial and astrocytic activation to disease onset and progression in a transgenic model of familial ALS. Glia 23(3):249-256

90. Keller AF, Gravel M, Kriz J (2009) Live imaging of amyotrophic lateral sclerosis pathogenesis: disease onset is characterized by marked induction of GFAP in Schwann cells. Glia 57(10):1130 1142. https://doi.org/10.1002/glia.20836

91. Levine JB, Kong J, Nadler M, Xu Z (1999) Astrocytes interact intimately with degenerating motor neurons in mouse amyotrophic lateral sclerosis (ALS). Glia 28(3):215-224

92. Halleskog C, Schulte G (2013) WNT-3A and WNT-5A counteract lipopolysaccharide-induced pro-inflammatory changes in mouse primary microglia. J Neurochem 125(6):803-808. https://doi.org/ $10.1111 /$ jnc. 12250

93. Zhu A, Shen L, Xu L, Chen W, Huang Y (2017) Suppression of Wnt5a, but not Wnts, relieves chronic post-thoracotomy pain via anti-inflammatory modulation in rats. Biochem Biophys Res Commun 493(1):474-480. https://doi.org/10.1016/j.bbrc.2017. 08.167

94. Valencia J, Martinez VG, Hidalgo L, Hernandez-Lopez C, Canseco NM, Vicente A, Varas A, Sacedon R (2014) Wnt5a signaling increases IL-12 secretion by human dendritic cells and enhances IFN-gamma production by CD4+ T cells. Immunol Lett 162(1 Pt A):188-199. https://doi.org/10.1016/j.imlet.2014. 08.015

95. Pereira C, Schaer DJ, Bachli EB, Kurrer MO, Schoedon G (2008) Wnt5A/CaMKII signaling contributes to the inflammatory response of macrophages and is a target for the antiinflammatory action of activated protein $\mathrm{C}$ and interleukin-10. Arterioscler
Thromb Vasc Biol 28(3):504-510. https://doi.org/10.1161/ ATVBAHA.107.157438

96. Blumenthal A, Ehlers S, Lauber J, Buer J, Lange C, Goldmann T, Heine H, Brandt E et al (2006) The Wingless homolog WNT5A and its receptor Frizzled-5 regulate inflammatory responses of human mononuclear cells induced by microbial stimulation. Blood 108(3):965-973. https://doi.org/10.1182/blood-2005-125046

97. Kumawat K, Gosens R (2016) WNT-5A: signaling and functions in health and disease. Cell Mol Life Sci 73(3):567-587. https:// doi.org/10.1007/s00018-015-2076-y

98. Halleskog C, Mulder J, Dahlstrom J, Mackie K, Hortobagyi T, Tanila H, Kumar Puli L, Farber K et al (2011) WNT signaling in activated microglia is proinflammatory. Glia 59(1):119-131. https://doi.org/10.1002/glia.21081

99. Libro R, Bramanti P, Mazzon E (2016) The role of the Wnt canonical signaling in neurodegenerative diseases. Life Sci 158:7888. https://doi.org/10.1016/j.lfs.2016.06.024

100. Biechele TL, Camp ND, Fass DM, Kulikauskas RM, Robin NC, White BD, Taraska CM, Moore EC et al (2010) Chemical-genetic screen identifies riluzole as an enhancer of Wnt/beta-catenin signaling in melanoma. Chem Biol 17(11):1177-1182. https://doi. org/10.1016/j.chembiol.2010.08.012

Publisher's Note Springer Nature remains neutral with regard to jurisdictional claims in published maps and institutional affiliations. 